\title{
A PARALLEL ASSESSMENT OF THE GROWTH PARAMETERS OF DIFFERENT LEGUMES GROWN IN CLODINAFOP STRESSED SOILS
}

\author{
Munees Ahemad ${ }^{1,2}$ \\ ${ }^{1}$ Department of Agricultural Microbiology, Faculty of Agricultural Sciences, Aligarh Muslim University, \\ Aligarh-202002, U.P., India \\ ${ }^{2}$ Department of Biology, College of Science, Bahir Dar University, Bahir Dar, Ethiopia \\ * Corresponding author: Dr. Munees Ahemad, Assistant Professor (Microbiology); currently affiliated with \\ Bahir Dar University, Bahir Dar, Ethiopia; Tel.: +91-571-2702945; muneesmicro@ rediffmail.com
}

\begin{abstract}
In modern agronomy, the indiscriminate and ill-advised application of herbicides leads to their accumulation in soils in substantial amounts and deteriorate the soil quality and fertility and in turn, the crop productivity. Earlier studies regarding the effect of herbicides were generally, restricted to a particular legume and studies about the concurrent impact of any specific herbicide on more than one legume are rare. This study was therefore, designed to evaluate the effect of the herbicide clodinafop simultaneously on four commonly grown food legumes (chickpea, pea, lentil and greengram). In this study, the growth of the selected legumes, in soils stressed with the recommended field application rate of clodinafop, decreased significantly. The root and shoot biomass, the symbiotic attributes (numbers, dry weight and leghaemoglobin content in nodules), nutrient-uptake (nitrogen and phosphorus), seed protein and yields of the tested legumes varied considerably in the presence of clodinafop. The toxic impact of clodinafop on nodule biomass, chlorophyll content, nutrient uptake and seed protein was marginal in all the tested legumes. In addition, clodinafop suppressed the root growth and seed yield in greengram, nodule numbers in pea and the shoot growth and leghaemoglobin content of nodules in chickpea. Overall, clodinafop showed the most adverse impact on the growth parameters of chickpea and greengram and the least on those of pea and lentil.
\end{abstract}

(Keywords: herbicide, clodinafop, toxicity, legume, soil)

\section{INTRODUCTION}

Globally, intensification of agricultural practices has resulted in a continuous increment of agrochemical consumption and the majority of agrochemicals commercialized are herbicides [1]. Presently, herbicides of various chemical families and activity spectrums are widely used in agricultural fields to control plant growth limiting weeds. Despite the beneficial impact of herbicides on agricultural productivity, incessant exposure of soils to herbicides results in considerable deleterious consequences [2]. The injudicious and indiscriminate application of these agrochemicals in the fields can generate long-term residues in food and the environment, leading to a burgeoning concern by consumers. Furthermore, interaction between soil microorganisms and herbicides may influence soil quality and fertility, because these biologically active chemicals may have deleterious effects on plant-beneficial microbial species which utilize and degrade these compounds and their by-products in soils [1].
Apart from their impact on the environment and food quality, some herbicides may also have negative effects on the crop development and the overall agricultural output [3]. Thus, numerous side effects together with decline in germination, the growth inhibition or the delayed development, reduction in yields have been reported in crop species [4]. In addition, herbicides are also known to cause changes in the incidence and severity of some plant diseases, possibly by affecting plant pathogens [5].

Clodinafop [(R)-2-[4-(5-chloro-3-fluoro-2pyridyloxy) phenoxy] propionic acid] (CAS No. 105512-06-9), an aryloxyphenoxypropionic herbicide belonging to chemical class oxyphenoxy acid ester, is used in crop production to control many grass weeds. Its mode of action on the target plants is through the inhibition of fatty acid biosynthesis. Most of the earlier studies of phyto-toxicity of herbicides are generally, restricted to a single crop and comprehensive data assessing the impact of any 
specific herbicide on more than one legume in parallel is rare. Hence, the present study was designed to evaluate the effect of clodinafop on four commonly grown legumes like, chickpea (Cicer arietinum L.), pea (Pisum sativum), lentil (Lens esculentus) and greengram (Vigna radiata L. Wiclzek) together so that a firm conclusion can be drawn about the effects of this herbicide on legumes.

\section{MATERIAL AND METHODS}

\section{Herbicide treatment}

The technical grade (a.i. 98\%) clodinafop was obtained from Parijat Agrochemicals (New Delhi, India). To prevent the degradation, the stock solution was prepared just prior to each experiment by dissolving the herbicide in a solvent (acetone). The recommended field application dose $(400 \mu \mathrm{g} / \mathrm{kg}$ soil $)$ of clodinafop was used for the experiments.

\section{Legume-growth measurement}

Seeds of the commonly grown legumes like, chickpea var. C235, pea var. arakle, lentil var. K75 and greengram var. K851 were obtained from the Indian Agricultural Research Institute (IARI), Pusa, New Delhi, India and surface sterilized with $70 \%$ ethanol, 3 min.; $3 \%$ sodium hypochlorite, 3 min.; rinsed six times with sterile water and dried. A total of 10 seeds of each legume were sown in clay pots $(25 \mathrm{~cm}$ high, 22 $\mathrm{cm}$ internal diameter) using three $\mathrm{kg}$ unsterilized soils [sandy clay loam, organic carbon (C) $0.4 \%$, Kjeldahl nitrogen $(\mathrm{N}) \quad 0.75 \mathrm{~g} \quad \mathrm{~kg}-1$, Olsen phosphorus (P) $16 \mathrm{mg} \mathrm{kg-1,pH} 7.2$ and water holding capacity $0.44 \mathrm{ml} \mathrm{g}-1$, cation exchange capacity $11.7 \mathrm{cmol} \mathrm{kg-1}$ and $5.1 \mathrm{cmol} \mathrm{kg-1}$ anion exchange capacity) with a control (without clodinafop) and a treatment with the recommended field application rate of clodinafop (in three replicates for each legume). Seeds of chickpea, lentil, greengram and pea were sown in October, November, March and November, respectively. Plants in each pot were thinned to three plants 10, 10, 7 and 7 days after sowing (DAS) of chickpea, lentil, greengram and pea, respectively. The pots were watered with tap water when required and were maintained in an open field.

\section{Biomass production and symbiotic attributes}

All plants for each treatment were removed at 135 DAS (at harvest stage) of chickpea, 120 DAS (at harvest stage) for both pea and lentil and 80 DAS (at harvest stage) for greengram. The root and shoot of each legume were carefully washed and oven dried at $800 \mathrm{C}$ and weighed. The nodulation in chickpea, pea and lentil was recorded at 90 DAS (pod fill stage) and that of greengram at 50 DAS (pod fill stage). Nodules from the root systems of each legume were separated, counted, oven dried at $80{ }^{\circ} \mathrm{C}$ and weighed. The leghaemoglobin $(\mathrm{Lb})$ content in fresh nodules recovered from the root system of each legume crop was quantified at 90 DAS each for chickpea and pea and lentil and 50 DAS for greengram, respectively, by the method of Sadasivam and Manickam [6]. Briefly, fresh nodules were crushed with the help of mortar and pestle in $5 \mathrm{ml}$ sodium phosphate buffer $(\mathrm{pH}$ 7.4) and filtered through two layers of cheese cloth. The nodule debris was discarded. The turbid reddish brown filtrate was clarified by centrifugation at $10000 \mathrm{~g}$ for $30 \mathrm{~min}$. The supernatant was diluted to $10 \mathrm{ml}$ with sodium phosphate buffer ( $\mathrm{pH} 7.4)$. The extract was divided equally into two glass tubes $(5 \mathrm{ml} /$ tube) and equal amount of alkaline pyridine reagent was added to each tube. The haemochrome formed was read at 556 and $539 \mathrm{~nm}$ after adding a few crystals of potassium hexacyanoferrate and sodium dithionite, respectively. The leghaemoglobin content was calculated using the formula -

Lb content $(\mathrm{mM})=\frac{\left[\mathrm{A}_{556}-\mathrm{A}_{539}\right] \times 2 \mathrm{D}}{23.4}$

Where $\mathrm{D}=$ initial dilution

\section{Total chlorophyll, nitrogen and phosphorus contents}

The total chlorophyll content in fresh foliage of each experimental legume crop was quantified at 90 DAS each for chickpea, pea and lentil and 50 DAS for greengram by the method of Arnon [7]. Briefly, one gram of fresh leaves of each legume was grinded in $40 \mathrm{ml}$ of $80 \%$ acetone with the help of mortar and pestle. The suspension was decanted in Buchner funnel having Whatman filter paper No. 1. The residue was grounded three times with acetone and the resulting suspension was filtered again. Contents in mortar-pestle was washed with $80 \%$ acetone and 
filtered. The filtrate was transferred to $100 \mathrm{ml}$ volumetric flask and volume was made upto 100 $\mathrm{ml}$. The absorbance was read at 645 and $663 \mathrm{~nm}$ using double beam UV-Visual spectrophotometer (Electronics Corporation of India Limited, India). The total chlorophyll content was calculated as -

Total chlorophyll $=\frac{\left[2.02\left(O D_{645}\right)+8.02\left(O D_{663}\right)\right] \times V}{1000 \times W}$

Where $\mathrm{OD}_{645}=$ optical density at $645 \mathrm{~nm}$, $\mathrm{OD}_{663}=$ optical density at $663 \mathrm{~nm}$ $\mathrm{V}=$ final volume of chlorophyll extract in $80 \%$ acetone and $\mathrm{W}=$ fresh weight of tissue extracted

The total $\mathrm{N}$ and $\mathrm{P}$ content in roots and shoots of chickpea (135 DAS), lentil (120 DAS), pea (120 DAS) and greengram (80 DAS) were measured by the micro-Kjeldahl method of Iswaran and Marwah [8] and the method of Jackson [9], respectively.

\section{Seed yield and grain protein}

Chickpea, pea, lentil and greengram were finally harvested at 135, 120, 120 and 80 DAS, respectively, and seed yield was measured. The protein content in grains of each legume was estimated by the method of Lowrey [10].

\section{Statistical analysis}

The experiments were conducted for two consecutive years with the identical environmental conditions and with the same herbicide treatment to ensure the reproducibility of the results. Since the data of the measured parameters obtained were homogenous, they were pooled together and subjected to analysis of variance. The difference among treatment means was compared by Tukey test at 5\% probability level.

\section{RESULTS}

In this study, the growth of four legume crops (chickpea, pea, greengram and lentil) grown in soils amended with clodinafop at the recommended field application rate was evaluated. The dry biomass of roots and shoots and the symbiotic attributes (numbers, dry weight and leghaemoglobin content in nodules) of each legume varied significantly under clodinafop-stress.
In general, clodinafop unfavorably decreased the biomass accumulation in both root and shoot of the selected legumes. Of the tested legumes, the greengram plants suffered the greatest decline in the root biomass in the presence clodinafop whereas the maximum toxicity of this herbicide to the shoot biomass accumulation was observed for the chickpea plants over their respective controls. Furthermore, the toxic effect of clodinafop on root biomass accumulation in pea and chickpea plants and shoot biomass accumulation in greengram and lentil was marginal. The order of the degree of toxicity (percent decline over the controls) of clodinafop to the root biomass accumulation was observed as: greengram (49) > lentil (10) > pea (8) > chickpea (4). on the contrary, the herbicidemediated percent reduction in the shoot dry matter accumulation in legumes over their controls was observed in the following order: chickpea (24) > pea (16) > greengram (6) > lentil (5) (Table 1).

The recommended dose of clodinafop had a negative impact on nodulation of the legumes. Clodinafop decreased the nodule numbers (percent decline over controls) in an order: pea (30) > greengram (10) > chickpea (5) = lentil (5). Comparative evaluation of nodule numbers of legumes does not give an exact assessment because size of nodules varies from one legume species to another. Both nodule dry biomass and $\mathrm{Lb}$ content are the parameters to assess the actual effect of any stress factor on nodulation. Therefore, these two symbiotic characteristics of legume were also determined. The inhibitory effect of clodinafop on nodule dry biomass of all legumes was comparatively similar and was found about $9 \%$ at an average less over their controls. Moreover, clodinafop affected Lb content in nodules of the tested legumes in the following sequence (percent decline over controls): chickpea (54) > greengram (12) > lentil (8) > pea (6) (Table 1). 
Table 1. Effect of clodinafop on dry biomass and symbiotic properties of legume crops

\begin{tabular}{|c|c|c|c|c|c|c|}
\hline \multirow[t]{2}{*}{ Legumes } & \multirow[t]{2}{*}{$\begin{array}{l}\text { Dose rate } \\
(\mu \mathrm{g} / \mathrm{kg} \text { soil })\end{array}$} & \multicolumn{2}{|c|}{$\begin{array}{l}\text { Dry biomass }(\mathrm{g} / \\
\text { plant })\end{array}$} & \multicolumn{3}{|c|}{ Nodulation } \\
\hline & & Root & Shoot & No./ plant & $\begin{array}{c}\text { Nodule } \\
\text { biomass } \\
\text { (mg/ plant) }\end{array}$ & $\begin{array}{c}\text { Leghaemoglobin } \\
\text { content } \\
{\left[\mathrm{mM} \text { (g.f.m.) }{ }^{-1}\right]}\end{array}$ \\
\hline \multirow[t]{2}{*}{ Chickpea } & 0 (control) & $0.91 \mathrm{~b}$ & $3.80 \mathrm{a}$ & $21 b$ & $180 \mathrm{c}$ & $0.13 \mathrm{c}$ \\
\hline & 400 & $0.87 \mathrm{c}$ & $2.83 b$ & $20 \mathrm{c}$ & $160 \mathrm{~d}$ & $0.06 \mathrm{~h}$ \\
\hline \multirow[t]{2}{*}{ Pea } & 0 (control) & $0.92 \mathrm{a}$ & $2.07 \mathrm{c}$ & $27 \mathrm{a}$ & $283 a$ & $0.17 \mathrm{a}$ \\
\hline & 400 & $0.85 \mathrm{~d}$ & $1.73 \mathrm{f}$ & $19 d$ & $253 b$ & $0.16 \mathrm{~b}$ \\
\hline \multirow[t]{2}{*}{ Greengram } & 0 (control) & $0.47 \mathrm{~g}$ & $2.08 \mathrm{c}$ & $21 b$ & $66 \mathrm{e}$ & $0.08 \mathrm{f}$ \\
\hline & 400 & $0.24 \mathrm{~h}$ & $1.95 \mathrm{~d}$ & $19 d$ & $61 \mathrm{f}$ & $0.07 \mathrm{~g}$ \\
\hline \multirow[t]{2}{*}{ Lentil } & 0 (control) & $0.55 \mathrm{e}$ & $1.97 \mathrm{~d}$ & $19 d$ & $30 \mathrm{~g}$ & $0.12 \mathrm{~d}$ \\
\hline & 400 & $0.50 \mathrm{f}$ & $1.87 \mathrm{e}$ & $18 \mathrm{e}$ & $28 \mathrm{~h}$ & $0.11 \mathrm{e}$ \\
\hline $\operatorname{LSD}(p \leq 0.05)$ & & 0.06 & 0.12 & 1.43 & 2.6 & 0.002 \\
\hline$F$ value & & 105.3 & 65.4 & 59.1 & 112.7 & 31.6 \\
\hline
\end{tabular}

Values are mean of three replicates where each replicate constituted three plants/ pot. Mean values followed by different letters are significantly different within a row or column at $\mathrm{p} \leq 0.05$ according to Tukey test; (g.f.m. $)^{-1}=(\text { gram fresh biomass })^{-1}$

Further, the effect of clodinafop on the total chlorophyll in fresh leaves of each legume was also evaluated. Generally, the chlorophyll content in leaves of the selected legumes decreased marginally over their control when grown in clodinafop amended soils. However, the most toxic effect of the herbicide was observed on the total chlorophyll of chickpea plants wherein the chlorophyll content declined 5\% over control (Table 2). Moreover, clodinafop decreased the root $\mathrm{N}$ by $6 \%$ in all the tested legumes except in greengram wherein clodinafop decreased root $\mathrm{N}$ by $3 \%$ compared to control. Similarly, the decline in the shoot $\mathrm{N}$ of all the selected legumes exposed to the herbicide-stress was found to be $4 \%$ excluding pea which suffered $7 \%$ reduction in shoot $\mathrm{N}$ above control (Table 2). In addition, the root $\mathrm{P}$ of the tested legumes in response to clodinafop exposure decreased marginally over controls in an order: pea $(10 \%)>$ chickpea $(6 \%)>$ lentil $(5 \%)>$ greengram $(4 \%)$. Similarly, the clodinafop mediated shoot $\mathrm{P}$ declined over controls as: pea $(11 \%)>$ chickpea $(10 \%)>$ lentil $(7 \%)>$ greengram $(6 \%)$ (Table 2 ).

Table 2. Effect of clodinafop on biological and chemical properties of legume crops

\begin{tabular}{|c|c|c|c|c|c|c|c|c|}
\hline \multirow[t]{2}{*}{ Legumes } & \multirow[t]{2}{*}{$\begin{array}{c}\text { Dose rate } \\
(\mu \mathrm{g} / \mathrm{kg} \text { soil })\end{array}$} & \multirow{2}{*}{$\begin{array}{l}\text { Chlorophyll } \\
\text { content } \\
(\mathrm{mg} / \mathrm{g})\end{array}$} & \multicolumn{2}{|c|}{$\begin{array}{c}\mathbf{N} \text { content } \\
(\mathrm{mg} / \mathrm{g})\end{array}$} & \multicolumn{2}{|c|}{$P$ content $(\mathrm{mg} / \mathrm{g})$} & \multirow{2}{*}{$\begin{array}{c}\text { Seed } \\
\text { protein } \\
(\mathrm{mg} / \mathrm{g})\end{array}$} & \multirow[t]{2}{*}{$\begin{array}{c}\text { Seed yield } \\
\text { (g/plant) }\end{array}$} \\
\hline & & & Root & Shoot & Root & Shoot & & \\
\hline \multirow{2}{*}{ Chickpea } & 0 (control) & $1.96 \mathrm{a}$ & $18 \mathrm{e}$ & $27 \mathrm{fg}$ & $0.17 \mathrm{f}$ & $0.21 \mathrm{f}$ & $241 c$ & $2.7 \mathrm{e}$ \\
\hline & 400 & $1.86 \mathrm{~b}$ & $17 \mathrm{f}$ & $26 \mathrm{~g}$ & $0.16 \mathrm{~g}$ & $0.19 \mathrm{~g}$ & $235 \mathrm{~d}$ & $2.4 \mathrm{~g}$ \\
\hline \multirow[t]{2}{*}{ Pea } & 0 (control) & $0.75 \mathrm{e}$ & $34 c$ & $45 c$ & $0.21 \mathrm{c}$ & $0.28 \mathrm{c}$ & $224 \mathrm{~g}$ & $7.4 \mathrm{a}$ \\
\hline & 400 & $0.73 \mathrm{f}$ & $32 \mathrm{~d}$ & $42 \mathrm{e}$ & $0.19 \mathrm{e}$ & $0.25 \mathrm{e}$ & $220 \mathrm{~h}$ & $7.1 \mathrm{~b}$ \\
\hline \multirow[t]{2}{*}{ Greengram } & 0 (control) & $0.82 \mathrm{c}$ & $36 a$ & $50 \mathrm{a}$ & $0.27 \mathrm{a}$ & $0.36 \mathrm{a}$ & $261 \mathrm{a}$ & $7.4 \mathrm{a}$ \\
\hline & 400 & $0.80 \mathrm{~d}$ & $35 \mathrm{~b}$ & $48 b$ & $0.26 \mathrm{~b}$ & $0.34 \mathrm{~b}$ & $258 \mathrm{~b}$ & $6.4 \mathrm{c}$ \\
\hline \multirow[t]{2}{*}{ Lentil } & 0 (control) & $0.32 \mathrm{~g}$ & $17 \mathrm{f}$ & $45 c$ & $0.21 \mathrm{c}$ & $0.28 \mathrm{c}$ & $232 \mathrm{e}$ & $3.0 \mathrm{~d}$ \\
\hline & 400 & $0.31 \mathrm{~h}$ & $16 \mathrm{~g}$ & 43de & $0.20 \mathrm{~d}$ & $0.26 \mathrm{~d}$ & $229 f$ & $2.6 f$ \\
\hline $\operatorname{LSD}(p \leq 0.05)$ & & 0.02 & 0.58 & 1.8 & 0.01 & 0.05 & 2.25 & 0.15 \\
\hline$F$ value & & 3.04 & 107 & 117.5 & 74.2 & 12.6 & 124.2 & 56.1 \\
\hline
\end{tabular}

Values are mean of three replicates where each replicate constituted three plants/ pot. Mean values followed by different letters are significantly different within a row or column at $\mathrm{p} \leq 0.05$ according to Tukey test. 
Moreover, clodinafop marginally decreased the seed protein of the selected legumes. Furthermore, seed yield of each legume was significantly decreased in the presence of clodinafop and the following decreasing trend (percent decline over controls) was observed as: greengram (14) > lentil (13) > chickpea $(11)>$ pea (4).

\section{DISCUSSION}

In our study, clodinafop adversely affected the growth of all tested legumes and significantly decreased their root and shoot growth and symbiotic attributes. The decline in growth of legumes following clodinafop application in our study could be due to the toxic effects of this herbicide on plant organs, especially the function of nodules which consequently disrupts the legume-Rhizobium symbiosis and hence, the N2 fixation and in turn the overall plant growth [3, 11]. Moreover, the toxicological effects of herbicides on the growth and metabolism of organisms may probably be attributed to the decline in enzymatic activities [12]. However, there is a great inconsistency in the reported results by other authors. For instance, the recommended dose of paraquat decreased the N2 fixation to a great extent whereas the same dose rate each of sethoxydim, alachlor, fluazifop butyl and metolachlor had no effect on the physiological functions of soybean plants [13]. In other studies, the phytotoxicity of terbutryn/terbuthylazine and bentazone to pea plants [14] and that of chlorimuron-ethyl to soybean plants [15] is well reported.

However, the degree of toxicity of clodinafop to the parameters to each legume varied considerably in our study. The variable response of the tested legumes to clodinafop is due to the fact that extent of toxicity of any specific herbicide to the plants depends upon the both genetics and physiology of plants which varies from one plant species to another [4]. In other study, Anderson et al. [16] reported that herbicides have detrimental impact on nodule formation in legume plants by decreasing the root biomass thus minimizing the attachment sites for the cognate rhizobia or by limiting the nutrient uptake by the newly formed nodules; decreasing root hairs infection owing to inefficient and incompetent rhizobia exposed to herbicide-stress; inhibiting the signaling molecules required to commence nodulation; and reducing cell division in turn, inhibiting nodulation.

Moreover, clodinafop, in our study, marginally decreased chlorophyll content measured at pod fill stage of chickpea (90 DAS), pea (90 DAS), greengram (50 DAS) and lentil (90 DAS) plants. As reported by Boldt and Jacobsen [17] that the pesticides adversely affect the metabolic enzymes, therefore, it seems probable that pesticides employed in this study might have inhibited the functioning of the enzymes of photosynthetic carbon reduction (PCR) cycle, such as Rubisco, 3-PGA kinase, NADP, NADGlyceraldehyde-3-P-dehydrogenase and aldolase. Nitrogen and $\mathrm{P}$ content of the legume plants is one of the most important aspects of legume growth. The nitrogen content in roots and shoots determined at different stages of chickpea, lentil, pea and greengram differed among treatments. The decrease in $\mathrm{N}$ contents of legumes might have been due to the reduction in legume-Rhizobium symbiosis, as indicated by a decline in the nodulation in this study. In agreement to this finding, Fox et al. [3] concluded that agrichemicals including herbicides induce a symbiotic phenotype that inhibits or delays recruitment of rhizobia to host plant roots, fewer root nodules produced, lowers the rate of nitrogenase activity which in turn reduces $\mathrm{N}$ content and decrease the overall plant yields at harvest. A similar reduction in $\mathrm{N}$ uptake in legume like chickpea following herbicides application has been reported [18]. However, the reduction in $\mathrm{P}$ content and seed attributes following herbicide application could probably, be due to inhibition of the enzymes and functional proteins of metabolic pathways involved in protein synthesis and P-uptake [4, 17]. In addition, it is reported that application of herbicides affect the photosynthetic pigments and photo-system II electron transport and therefore, the process of photosynthesis which in turn inversely affect the vegetative growth and seed yield of crops $[18,19,20]$. 


\section{CONCLUSION}

Clodinafop showed a varying degree of toxicity to the tested legumes. The inhibitory effect of clodinafop on nodule biomass, chlorophyll content, nutrient uptake ( $\mathrm{N}$ and $\mathrm{P}$ ) and seed protein was minor in all the tested legumes with respect to their untreated controls. However, clodinafop displayed the maximum phytotoxicity to the root growth and seed yield in greengram, nodule numbers in pea and the shoot growth and $\mathrm{Lb}$ content of nodules in chickpea. Generally, clodinafop showed the most adverse impact on the growth parameters of chickpea and greengram.

\section{ACKNOWLEDGEMENT}

The authors express gratitude to Dr. N. A. Naqvi, Parijat Agrochemicals, New Delhi, India, for providing technical grade clodinafop. Financial assistance from University Grants Commission (UGC), New Delhi, India is thankfully acknowledged.

\section{REFERENCES}

1. Zabaloy, M.C., and Gómez, M.A., (2005). Diversity of Rhizobia Isolated from an Agricultural Soil in Argentina Based on Carbon Utilization and Effects of Herbicides on Growth. Biology and Fertility of Soils 42: 83-88 pp.

2. Ahemad, M., and Khan, M.S., (2010a). Influence of Selective Herbicides on Plant Growth Promoting Traits of Phosphate Solubilizing Enterobacter asburiae Strain PS2. Research Journal of Microbiology 5: 849-857 pp.

3. Fox, J.E., Gulledge, J., Engelhaupt, E., Burow, M.E., and McLachlan, J.A., (2007). Pesticides Reduce Symbiotic Efficiency of Nitrogen-Fixing Rhizobia and Host Plants. PNAS 104: 10282$10287 \mathrm{pp}$.

4. Ahemad, M., and Khan, M.S., (2010b). Advances in Pesticide Toxicity to RhizobacteriaLegume Symbiosis: Problems and Remedies. Lambert Academic Publishing (LAP), Germany.

5. Heydari, A., Misaghi, I.J., and McCloskey, W.B., (1997). Effects of Three Soil-Applied Herbicides on Populations of Plant Disease Suppressing Bacteria in the Cotton Rhizosphere. Plant and Soil 195: 75-81 pp.
6. Sadasivam, S., and Manikam, A., (1992).

Biochemical Methods for Agricultural Sciences. Wiley Eastern Limited, New Delhi, India.

7. Arnon, D.I., (1949). Copper Enzymes in Isolated Chloroplats, Polyphenol Oxidase in Beta vulgaris. Plant Physiology 25: 1-15 pp.

8. Iswaran, V., and Marwah, T.S., (1980). A Modified Rapid Kjeldahl Method for Determination of Total Nitrogen in Agricultural and Biological Materials. Geobios 7: 281-282 pp.

9. Jackson, M.L., (1967). Soil Chemical Analysis. Prentice-Hall of India, New Delhi.

10. Lowery, O.H., Rosebrough, N.J., Farr, A.L., and Randal, R.J., (1951). Protein Measurements with the Folin Phenol Reagent. Journal of Biological Chemistry 193: 265-275 pp.

11. Evans J., Seidel J., O'Connor G.E., Watt J., and Sutherland M., (1991). Using Omethoate Insecticide and Legume Inoculant on Seed. Australian Journal of Experimental Agriculture 31: 71-76 pp.

12. Zablotowicz, R.M., and Reddy, K.N., (2004). Impact of Glyphosate on the Bradyrhizobium Japonicum Symbiosis with Glyphosate-Resistant Transgenic Soybean: A Minireview. Journal of Environmental Quality 33: 825-831 pp.

13. Kucey, R.M.N., Janzen, H.H., and Leggett, M.E., (1989). Microbiology Mediated Increases in Plant Available Phosphorus. Advances in Agronomy 42: 199-288 pp.

14. Singh, G., and Wright, D., (2002). Effects of Herbicides on Nodulation and Growth of Two Varieties of Peas (Pisum sativum). Acta Agronomica Hungarica 50: 337-348 pp.

15. Zawoznik, M., Tomaro, S., and María, L., (2005). Effect of Chlorimuron-Ethyl on Bradyrhizobium japonicum and its Symbiosis with Soybean. Pest Management Science 61: 1003-1008 pp.

16. Anderson, A., Baldock, J.A., Rogers, S.L., Bellotti, W., and Gill, G., (2004). Influence of Chlorsulfuron on Rhizobial Growth, Nodule Formation, and Nitrogen Fixation with Chickpea. Australian Journal of Agricultural Research 55: 1059-1070 pp. 
17. Boldt, T.S., and Jacobsen, C.S., (1998). Different Toxic Effects of the Sulphonylurea Herbicides Metsulfuron Methyl, Chlorsulfuron and Thifensulfuron Methyl on Fluorescent Pseudomonads Isolated from an Agricultural Soil. FEMS Microbiology Letters 161: 29-35 pp.

18. Khan, M.S., Chaudhry, P., Wani, P.A., and Zaidi, A., (2006). Biotoxic Effects of the Herbicides on Growth, Seed Yield, and Grain Protein of Greengram. Journal of Applied Sciences and Environmental Management 10: 141-146 pp.

19. Eilers, R.J., Crouse, G.D., Durst, G.L., Manly, C.J., Webster, J.D., and Streusand, V.J., (1992). Inhibition of Photosystem II Electron Transport and Structure-Activity Relationships among Herbicidally Active 3-Butenanilides. Pesticide Biochemistry and Physiology 43: 162$170 \mathrm{pp}$.

20. Grossman, K., Hass, H.U., and Hurle, K., (2000). Cinidone-Ethyl (Lotus R): Studies on the Mode of Action and Selectivity and Behavior in Combination with Auxin Herbicides. Zeitschriftfur-pflazenkrankheiten-und-pflazenchutz 17: 509-516 pp. 